\title{
THE EVALUATION FORMS OF INTERNATIONAL PASSENGER AIRPORT HUB IN SOUTHEAST ASIA
}

\author{
Nattapong Jantachalobon* \\ University of Thai Chamber of Commerce, School of Engineering, Bangkok, Thailand \\ Nanthi Suthikarnnarukhi \\ University of Thai Chamber of Commerce, School of Engineering, Bangkok, Thailand
}

This research aims to present the selection of Asean international airports in order to establish the international passenger airport hub in Southeast Asia. The study focused on the airports in Southeast Asia region which most passengers travelling through as follows : Singapore's Changi International Airport (SIN), Cambodia's Phnom Pehn International Airport (PNH), Brunei's Brunei international Airport (BWN), Indonesia's Sugarno Hatta International Airport (CGK), Lao PDR's Wattay International Airport (VTE), Malaysia's Kuala Lumpur International Airport (KUL), Myanmar's Rangoon International Airport (RGN), the Philippines' Ninoy Aquino International Airport (MNL), Thailand's Suvarnabhumi International Airport (BKK), and Vietnam's Tan Son Nhat International Airport (SGN) as the optional airports. In order to acquire the most suitable areas in the engineering perspective, the Multiple Criteria Decision Making (MCDM) has been applied by using both Technique for Order Preference by Similarity to Ideal Solution-TOPSIS and Analytic Hierachy Process-AHP. There are 5 main criterions to be considered consisting of Geographical factors, Economic Factors, Functional Factors, Operational Factors and other factors. The two main research methodology to gain these factors which effecting the establishment of airport hubs consist of Delphi method and Regression analysis. The research will be the benefits for managing airports and developing their airport hub. Moreover the study of the research will be useful for Southeast Asia governments to determine the relevant policies and planning for aviation business development of the country.

Key words: Multiple Criteria Decision Making, Airport Hub, Southeast Asia, Delphi Method, Regression Analysis

\section{INTRODUCTION}

The leaders of 10 member countries affirmed their strong commitment to acceleration of an ASEAN Community by 2015 . The AEC will transform ASEAN into a region with free movement of goods, services, investment, skilled labor and free flow of capital. The air transport is a method to travel within the region and connect to other regions in the world. Moreover the business competition nowadays tends to be more intensive due to the globalization and free trade agreement. The intense of business competitiveness, both in production and in marketing, results in the business entities need to enhance their competitive capacity in every possible ways. The statistics of World Bank during 1995-2013 shows that the growth of passengers in Southeast Asia region has been increasing. Therefore all airports and airlines need to prepare to deal with these passengers. The airport develop- ment and the adjustment of aviation routes and services require to be improved to create more profit for their businesses. The selection of the international airport to be the passenger hub in Southeast Asia region and connect to other regions in the world is the most important measure to reduce operating costs and save time for the aviation business.

The objective of this research is to select the suitable airport which will be the aviation hub in Southeast Asia region. The study emphasizes on the international airports which have most air passenger traffic volume as follows: $(\mathrm{ACl}, 2013)$ Singapore's Changi International Airport (SIN),Cambodia's Phnom Pehn International Airport (PNH),Brunei's Brunei international Airport (BWN), Indonesia's Sugarno Hatta International Airport (CGK), Lao PDR's Wattay International Airport (VTE), Malaysia's Kuala Lumpur International Airport (KUL), Myanmar's Rangoon International Airport (RGN), the Philip- 
pines' Ninoy Aquino International Airport (MNL), Thailand's Suvarnabhumi International Airport (BKK), and Vietnam's Tan Son Nhat International Airport (SGN). The research applied the engineering principles to solve the selection problem systematically and reasonably. The research methodology consists of multiple liner regression, Delphi method, Concentration Ratio (CR), Comprehensive Concentration Index-CCl, Herfindahl-Hirschman index $(\mathrm{HHI})$ and Multiple Criteria Decision Making (MCDM). The researcher applied Technique for Order Preference by Similarity to Ideal Solution (TOPSIS) and Analytics Hierarchy Process (AHP) for data analysis.

The rest of this paper is organized as the following sections. Section 2 will discuss on the methods and factors which affects the airport hub evaluation worldwide. Section 3 will show the process of airport hub evaluation in Southeast Asia. The process begins with finding of affected factors to be airport hub worldwide and execute these data using multiple liner regression method with the airports where most passenger traffic in 6 regions: Africa's O.R. Tambo International Airport, Europe's London Heathrow Airport, Middle East's Dubai International Airport, North America's Hartsfield-Jackson Atlanta International Airport, South America's São Paulo-Guarulhos International Airport, and Asia Pacific's Beijing Capital International Airport (ACl statistic,2013). The same data then was executed, using the same method (MLR), with 10 international airports in Southeast Asia region. Lastly, the Delphi method will be used to find the possible factors of airport hub. The result from 3 methodologies will be compared and evaluated all factors to select the suitable airport hub in Southeast Asia region. Section 4 shows the result of the research and analysis of the selective airport hub for Southeast Asia region. Section 5 provides conclusions and suggestions.

\section{LITERATURE REVIEW}

There is the intensive competition in aviation business. The transfer of workforce, merchandise, capital and data are increasing. Bowen (2000) has studied the change of aviation industry growth in Southeast Asia region and found that the national government applied their strategies which are airline industry liberalization and airport development, to shape the development of air transport network. O'Connor (1995) studied the changes of pattern of traffic and activity of airline in Southeast Asia. This research is the basis of planning in transport geography.

There have been many methods used in past studies for evaluating the airport hub. Costa (2010) found airport hub for tourism in Brazil by using 3 methods for evaluating tourist airport hub consisting of: firstly, surveying with Brazilian experts, secondly US Federal Aviation Administration and thirdly the usual Herfindahl-Hirschman method. Janic and Reggiani (2002) used the Multiple criteria decision making (MCDM) in order to select new hub airport in Europe. They evaluated 7 airports in Europe by applying 3 methods of MCDM as follows: SAW (Simple Additive Weighting), TOPSIS (Technique for Order Preference by Similarity to the Ideal Solution) and AHP (Analytic Hierarchy Process). Scholz (2011) analyzed the airline network by calculating Herfindahl-Index $(\mathrm{HI})$, the concentration-ratio (CR) and the Gini-Index (GI). These analysis results in the market share of each airlines. The study of Wang (2011) concerned the airport city in Taiwan used 30 key factors and seven trends for airport-city development by interviewing the group of experts. Carmona-Benítez MRes, R.B \& Lodewijks, $G$ was set up by analyzing the domestic US air transport market. A multi-regression analysis determined the relation between distance, airline operations costs and airports charges between origin and destination and market fares. Müller, J, Ülkü, T, and Živanović, $\mathrm{J}(2009)$ compare analysis of the economic and technical performance of thirteen airports from 1998 to 2005. Methods used are Partial Factor Productivity (PFP), Data Envelopment Analysis (DEA), Stochastic Frontier Analysis (SFA) and Second Stage Multi Regressions, which are applied to identify the characteristics of British and German airports and compare two different ownership structures: privatized and partially privatized with residual public ownership.

Previous study about airport hub factor, Dennis, 1994 studied the airline hub operations in Europe giving the importance of the distance factor in order to minimize connecting time and costs. The finding of Dennis's study shows that Amsterdam and Paris international airports are suitable to develop as the regional hub. Matsumoto (2007) also studied the density of air passenger traffic in Asia, Europe, and America by using the following factors: GDP, population and distance. The study measured the density traffic suitable to be airport hub. Nenem (2012)'s study applied 
the method of Geographical Positioning as the main factor to determine airport hub in Europe, middle East and North Africa and find the best position which can reduce the operating costs for the airlines. Lin (2010)'s study found that Low cost airline and airport in Southeast Asia have develop their relations such as: signing on bilateral air service agreement which these airports tend to be airport hub. The key indicator for the airlines chooses that airport to be the airline base for connecting to various aviation routes. Salmon Smith Barney said that the factors needed to consider aviation hub are size of Natural Catchment Area, Location Relative to Main Traffic Flows Aviation Hub, Attractiveness to Connecting Traffic, Strength and Commitment of the Home Airline or Alliance, and Airport Expansion Potential. Park (2003) assessed the competitive status of major airports in East Asia based on five factors: service, demand, managerial, facility and spatial qualities.

\section{METHODOLOGY}

This research aims to evaluate the most suitable airport in Southeast Asia for being air passenger airport hub by using two main methodologies comprising of multiple liner regression analysis and Delphi technic. These technics used to find the relation of all factors affecting to be airport hub. In the selection of the sample group, researcher applied the methods of $\mathrm{CR}, \mathrm{CCl}, \mathrm{HHI}$ to analyze the economic factor suitable to be airport hub. AHP and TOPSIS methods are used to evaluate the airport in Southeast Asia and determine which airport suits to be airport hub of the region. The research methodology can be shown in detail as the following chart below. (Figure 1)

Step 1 Set up international pass enge $r$ airport hub model in Southeast A sia

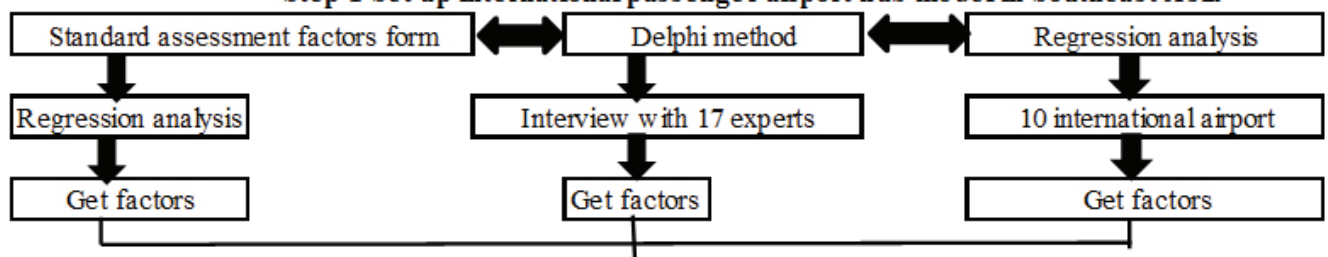

Sum and mixed of factor that come from 3 methods

Step 2 Select the sample group of international passenger airport in Southeast Asia

\begin{tabular}{|l|l|l|l|l|l|}
$\begin{array}{l}\text { Review passenger traffic } \\
\text { statistics in each } \\
\text { intema tional airport }\end{array}$ & $\begin{array}{l}\text { Analysis data and compare with each } \\
\text { international passenger a irport in } \\
\text { Southeast Asia by using CR, CCI, HHI }\end{array}$ \\
\hline
\end{tabular}

Step 3 Set up we ight factors criteria and collect data follow as international passenger airport hub model in Southeast Asia

\begin{tabular}{|l|l|l|l|}
\hline \multicolumn{2}{|c|}{ Quantitative data } & \multicolumn{1}{|l|}{ Experts pairwaise comparison } \\
\hline secondary data & Clsassify data in 5 levels & 17 experts \\
\hline
\end{tabular}

Step 4 Analysis the appropriate choice by using multi-criteria decision analysis

$\underbrace{\text { TOPSIS }}_{\text {A irport ranking }}$

Figure 1: Steps of research methodology

\section{The selection of factors in relation to airport hub}

The selection of factors uses both qualitative and quantitative methods by making literature review from relevant journals, books and other documents in the past concerning the factors affecting the selection of air passenger hub worldwide. It is found that there is no journal mentioned of the standard factor using in evaluating airport hub. From literature review, it is found in conclusion that there are 5 main factors and 21 sub factors. The data using to analyze these factors come from the raw data of both public and private entities as shown in Table 1. The main factors and sub factors are used to find their relations by using the mean of multiple linear regression analysis. The sample group consists of all airports in the world categorized by the most number of air passenger traffic in each region. It can be divided into 6 regions (FAA, 2013) according to Airports Council International as the following: Africa, Europe, Middle East, North America, South America, and Asia Pacific. Next step is the use of multiple regression analysis as the first step but the sample groups are 10 international airports in Southeast Asia region. The last step 
is the use of Delphi technic to find the relation of these variables by interviewing 17 experts from 5 target groups from various aspects in Thailand such as: government, academia, airline, airport management, and economic policy. The study of California Junior Colleges Association, 1971 stated that if the expert target groups more than 17 or more, the error from analysis will be reduced. Analysis by Delphi technic will be made
3 times. In the first round of analysis the open questionnaire is used. The second round will use the questionnaire of rating scale 5 in accordance with the theory of Likert scale. Lastly there will be the answer confirmation of each expert. Then the results from all three methods will be compared and analyzed to reflect the factors are related to being airport hub.

Table 1: Summary of passenger airport hub criteria in past studies

\begin{tabular}{|c|c|}
\hline Locational Factors & Previous Study \\
\hline Linking/Gateway & $\begin{array}{l}\text { O'Connor (1995); Bowen (2000); Costa (2009); } \\
\text { Zhang (2002) }\end{array}$ \\
\hline Economic Factors & Previous Study \\
\hline GDP & $\begin{array}{l}\text { Bowen (2000); Zhang (2002); Kang (2003); Hom- } \\
\text { sombat et al. (2011) }\end{array}$ \\
\hline GDP Growth & Homsombat et al. (2011) \\
\hline GDP per Capital & Homsombat et al. (2011) \\
\hline Employment Rate & Homsombat et al. (2011) \\
\hline Unemployment Rate & Homsombat et al. (2011) \\
\hline Total Investment & Homsombat et al. (2011) \\
\hline Functional Factors & Previous Study \\
\hline Minimum Connection Time & Dennis (1994); Nenem and Ozkan-Gunay (2012) \\
\hline Number of Principal Runways & Dennis (1994) \\
\hline Terminal Capacity & $\begin{array}{l}\text { Kang (2003) Wit (1996); Ohashi et al. (2005); } \\
\text { Berechman and de Costa (2009); Homsombat et } \\
\text { al. (2011) }\end{array}$ \\
\hline Passenger Airport Charge & Berechman and de Wit (1996) \\
\hline Number of custom clearance point & Zhang (2002) \\
\hline Operational Factors & Previous Study \\
\hline Number of Passenger Traffic & $\begin{array}{l}\text { Zhang (2002); Costa (2009); Watanabe (2009); } \\
\text { Nenem and Ozkan-Gunay (2012); Homsombat et } \\
\text { al. (2011) }\end{array}$ \\
\hline Number of Tourist Arrivals & $\begin{array}{l}\text { Homsombat et al. (2011); Berechman and de Wit } \\
(1996)\end{array}$ \\
\hline Number of Airline Company & Homsombat et al. (2011) \\
\hline Number of Aircraft Movement & $\begin{array}{l}\text { Watanabe (2009); Costa (2009); Nenem and Oz- } \\
\text { kan-Gunay (2012) }\end{array}$ \\
\hline Number of International Airport & Homsombat et al. (2011); Watanabe (2009); \\
\hline Other Factors & Previous Study \\
\hline Open Sky Policy & \begin{tabular}{|l} 
Tsai and Su (2002); Gardiner (2005); Lirn (2006); \\
Songguang (2007); Costa (2009); Wanga (2010)
\end{tabular} \\
\hline Number of Partnership between airport and airlines & $\begin{array}{l}\text { Homsombat et al. (2011); Fu et al. (2011); Barbot } \\
\text { (2009); Fu and Zhang (2010); Zhang et al. (2010) }\end{array}$ \\
\hline Maintenance/Repair/Overhaul & Homsombat et al. (2011) \\
\hline Population & Homsombat et al. (2011) \\
\hline
\end{tabular}




\section{Select the sample group}

This research aims to find the international airport which have the most air passenger traffic volume in each country in Southeast Asia region and propose to be the suitable airport hub for the region. Nevertheless all countries are different in any aspects such as economics, sociological, political, culture and airport management strategies. The method to select the sample group in analysis of the research consists of Concentration Ratio (CR), Herfindahl-Hirschman index $(\mathrm{HHI})$ and Comprehensive Concentration Index $(\mathrm{CCl})$. These methods result the concentration of the air passengers volume of various airports in Southeast Asia region during 1995-2013 using data from official airline guides (OAG) In order to clarify the acquisition of the sample groups clearly in this research, the selection methods used in this research can be described briefly as follows:

Concentration ratio is a tool which calculates the market share of each specific airport. The results reflect intense competition within the market. The calculated results can be divided into three levels:

1. CRn of $67 \%$ or more reflects high airport concentration with an evident monopoly.

2. CRn between $34 \%$ and $67 \%$, reflects an airport as moderately concentrated.

3. CRn of less than $34 \%$, reflects an airport with low concentration and that is highly competitive.

The formula for finding the concentration ratio is the following (Hallo, 1967):

$$
C R_{n}=\frac{\sum_{i=1}^{n} S_{i}}{\sum_{i=1}^{t} S_{i}} \times 100
$$

$\mathrm{CRn}=$ the ratio of major airport concentration

$\mathrm{Si}=$ selling revenue

$\mathrm{t}=$ the largest airport

$\mathrm{n}=$ total number of the airport in the industry

$\mathrm{i}=$ individual airport enterprise

Herfindahl-Hirschman index $(\mathrm{HHI})$ is an index to show the quadratic sum of each airport's market share compared to the whole industry. Where Si is the share of air traffic at airport $i$ in relation to the total air traffic. The variable $\mathrm{n}$ denotes the number of airports in the network. The $\mathrm{HHI}$ takes into account the relative size and distribution of the nodes (e.g. airports) in the network. It is size- dependent and its minimum for a fixed number of actors results in equal shares with a value of $1 /$ t. Furthermore, the $\mathrm{HHI}$ is primarily sensitive to changes at the extreme ends, which is a property of the square-function giving high weights to the largest airports. The $\mathrm{HHI}$ is the most frequently used measure of market concentration.

The results of analysis can be divided into 4 ranges:

1. Less than 1,000 means the market has high competition but no monopoly

2. Between 1,000 and 1,800 means there is moderate competition in the market and if $\mathrm{HHI}$ is close to 1,800 , a major market share enterprise exists.

3. More than 1,800 means there may be a monopoly in the market

4. More than 10,000 means there is only one service provider which holds a monopoly in the industry.

The formula for $\mathrm{HHI}$ is as follows (Hirschman, 1964):

$$
H H I=\sum_{i=1}^{t} S_{i}^{2}
$$

Comprehensive Concentration Index $(\mathrm{CCl})$ measures concentration, but adjusts the disclose defects of $\mathrm{HHI}$. Both $\mathrm{HHI}$ and $\mathrm{CCl}$ consider all enterprises in an industry but $\mathrm{CCl}$ emphasizes enterprises other than biggest entity. $\mathrm{CCl}$ gives a value between 1 and 0 , and a result close to 1 indicates a monopoly is present in the market. The formula CCl is as follows (Horvath 1970):

$$
C C I=S_{i}+\sum_{j=2}^{t} S_{j}^{2}\left[1+\left(1-S_{j}\right)\right]
$$

$\mathrm{CCl}=$ Comprehensive Concentration Index

$\mathrm{Si}=$ the market share of the airport no. $\mathrm{i}$ : $\mathrm{i}=1,2,3,4, \ldots, \mathrm{n}$

$\mathrm{Sj}=$ the market share of the airport no. $\mathrm{j}$ : $\mathrm{j}=1,2,3,4, \ldots, \mathrm{n}$

\section{Survey results of weights criteria and collect data from international airport hub model}

$\mathrm{AHP}$ is used to find weight measurement of each criteria and secondary data from government agencies, private sectors and annual report of each international airport. The level of measurement can be divided into 5 combining with the collecting of raw data according to variable factors. 
In AHP relative measurement, a comparison matrix at each level will be set up by comparing pairs of criteria, or pairs of alternatives at the lowest level. A scale of scores ranging from 1 (equally important) to 9 (absolutely important) is used to denote the importance of these criteria/ alternatives. Once the matrix of pairwise comparisons has been developed, the relative importance of each can be estimated in terms of the specific measure. Pairwise comparisons between the $\mathrm{m}$ measures can be conducted by asking the decision-maker or expert questions such as, "Which measure is more important with regards to the decision goal and the extent of its importance?" (Score 1-9). The answers to these questions for man $\mathrm{m} * \mathrm{~m}$ pairwise comparison matrix, which is defined as follows (Saaty, 1980; Saaty, 1994):

$$
A=\left(a_{i j}\right)_{m \times m}=\left[\begin{array}{cccc}
a_{11} & a_{12} & \cdots & a_{1 m} \\
a_{21} & a_{22} & \cdots & a_{2 m} \\
\vdots & \vdots & \ddots & \vdots \\
a_{m 1} & a_{m 2} & \cdots & a_{m m}
\end{array}\right]
$$

In Eq. (1), aij represents a quantified judgment on wi/wj with aii $=1$ and aij $=1 /$ aji for $\mathrm{i}, \mathrm{j}=1, \ldots$, $\mathrm{m}$. The weight of measure i can be calculated as follows:

$$
W_{i}=\frac{1}{m} \sum_{j=1}^{m} \frac{a_{i j}}{\sum_{i=1}^{m} a_{i j}} i, j=1,2, \ldots \ldots, m
$$

To determine the range of international passenger airport data, researcher considers the range of real data each international passenger airport in Southeast Asia. It can divide the data into 5 levels to complete. Accordance with the process set points for sequence analysis tactic (Analytic Hierarchy Process, AHP) is also consistent with the research of Deng Yong (2006), which details the calculations are as follows:

The range $=$ Max value data - Min value data The class interval width $=$ the range/number of layer data

\section{Development of passenger airport hub factors to evaluation model for selection}

This section discusses the results of factors to evaluate how any international airport become airport hub in Southeast Asia region. AHP method and TOPSIS method will be used to classify the most suitable airport as a hub for the region. The study of TOPSIS method is about concept and process of implementation. It shows that this method focus on criteria which is separation between the positive and negative criteria. And at the end of the analysis, including the assessment of the two types together seamlessly. Thus the answer is more reliable.

AHP is the method to find weight of criteria by comparing pairs of alternatives for decision making. The criteria will be orderly classified from main criteria to minor criteria.

The different between AHP and TOPSIS

1. AHP give effectively analyze data in tangible and intangible especially, the important topic in deciding on a judge style.

2. TOPSIS is good at analysis in feeling decision.

3. TOPSIS want a certain style in order to determine the relative importance of different features of the factor criteria.

4. AHP makes decisions that are more flexible and good ranking in factors criteria.

5. AHP calculations are more complicated than TOPSIS.

6. AHP factors and alternatives are compared in pairs while TOPSIS no comparison in pair.

7. TOPSIS is to select the best method from data, but may not be the most appropriate.

8. TOPSIS use tree method but AHP hierarchy mapping relationship.

9. TOPSIS will not charge when the weight is zero, which is a disadvantage.

\section{ANALYSIS AND RESULTS}

Step 1: The results of factors relating to be the passenger airport hub come from the comparison of 3 methods using regression analysis to find factors from 6 airports of 6 regions. Then regression analysis was used to find factors from 10 airports of 10 countries in Southeast Asia region. Finally, Delphi technic used to find the variables from interviewing the experts. The results of analysis are shown in table 2 . It is shown that there are 16 sub factors from analysis. Moreover the number of gateway, number of aircraft movement, number of tourist arrival, and number of partnership between airport and airline are related to the passenger airport hub. 
Table 2: Summary of passenger airport hub factor from three methods

\begin{tabular}{|c|c|c|c|c|}
\hline Methods & & Regression Analysis & Regression Analysis & \\
\hline Factors & Delphi & factor hub in the world & factor hub in ASEAN & SUM \\
\hline Number of Gateway & 1 & 1 & I & 3 \\
\hline Gross Domestic Product & 1 & & 1 & 2 \\
\hline Investment in Transportation & 1 & & 1 & 2 \\
\hline Minimum Connecting Time & 1 & & & 1 \\
\hline Terminal Capacity & 1 & & 1 & 2 \\
\hline Number of Custom Channel & 1 & & 1 & 2 \\
\hline Number of Aircraft Movement & 1 & 1 & 1 & 3 \\
\hline Number of airline company & 1 & & 1 & 2 \\
\hline Airport passenger charge fee & & 1 & 1 & 1 \\
\hline Number of tourist arrival & 1 & I & 1 & 3 \\
\hline Number of employment rate & & 1 & 1 & 2 \\
\hline Population & & 1 & & 2 \\
\hline Number of Airport & 1 & 1 & 1 & 1 \\
\hline $\begin{array}{l}\text { Number of Partnership } \\
\text { between Airport and Airlines }\end{array}$ & & I & 1 & 3 \\
\hline $\begin{array}{l}\text { Gross Domestic Product } \\
\text { Growth }\end{array}$ & & & 1 & 1 \\
\hline $\begin{array}{l}\text { Gross domestic product per } \\
\text { capital }\end{array}$ & & & 1 & 1 \\
\hline
\end{tabular}

Step 2: The sample group which will be selected to evaluate will be determined by 3 methods; $\mathrm{CR}, \mathrm{CCl}$ and $\mathrm{HHI}$. Table 3 and figure 2 shown the results of Changi International Airport, CR1 (SIN) in Singapore is the international airport that have highly market share in ten international airports of ASEAN. It has average means $26.33 \%$. Secondly, Suvarnabhumi International Airport, CR2 (BKK) in Thailand has a market share of second rank. It has $22.03 \%$ for average means. Sugarno Hatta International Airport, CR3 (CGK) in Indonesia has $16.98 \%$ for average means and come be third rank. Kuala Lumpur International Airport, CR4 (KUL) in Malaysia has $14.66 \%$ for average means and come be fourth rank. Manila Ninoy Aquino International Airport, CR5 (MNL) in Philippines has $11.74 \%$ for average means and come be Fifth rank. Finally, Tan Son Nhat International Airport, CR 6 (SGN) Vietnam has 5.6 for average means and come be sixth rank. The combined CR for these 6 airports exceeds 97.35 percent. The highest concentration ratio (CR1) was Changi International Airport. This illustrates that airline networks in ASEAN have high airport concentration. $\mathrm{CCl}$ shows that the market is highly competitive and not monopolized. It should be noted that ASEAN international airports are not different from each other, in the number of airline flights they service. There is no clear leader among ASEAN airports. Every ASEAN airport could be a hub. Moreover, The $\mathrm{HHI}$ illustrates that there is moderate competition in each airport. So, we selected the three most concentrated airports (CR1, CR2, CR3, CR4, CR5, and CR6) to analyze the next step.

Step 3: Finding weight criteria factors from 17 experts and raw data to evaluate the airport hub factor. The weight criteria divide into 5 levels in order to evaluate by using the method of AHP and TOPSIS. The result from figure 3 and figure 4 shown that geography criteria which is sub - criteria on number of gateway has the most, therefore the airport with most gateways, the more to be the airport hub. The criteria on operational and functional have the same weight. The factor on population has least weight, it is shown that Indonesia with most population among Asian countries have no effect to be the airport hub. Table 4 shows the level of evaluation for each factors dividing into 5 levels and 9 rating score. The evaluation comes from the actual data from various agencies in order to select the most suitable airport hub for the region.

Step 4: The decision making by applying TOPSIS method is the mean to realize the importance 
of positive and negative data. The procedure of analysis divided into several steps including the adjustment of standard value and multiplies with weight number and then lead to closeness coefficient. The result of analysis can be shown in table 5. The importance weight criteria using AHP method applied on the actual data of 5 levels and 9 score in step 3 . The matrix table will be used to evaluate and find consistency index which the results of analysis shown in Table 6.

\section{CONCLUSION}

The application of decision making model to evaluate the international airports in Southeast Asia region as airport hub reflects 6 airports as follows: 1. Changi international airport, (SIN) in Singapore 2. Suvarnabhumi International Airport, (BKK) in Thailand 3. Sugarno Hatta International Airport, (CGK) in Indonesia 4. Kuala Lumpur International Airport, (KUL) in Malaysia 5. Manila Ninoy Aquino International Airport, (MNL) in Philippines 6. Tan Son Nhat International Airport, (SGN) Vietnam. It is found that, from the importance weight criteria, geography criteria and sub-criteria of number of gateway is the most important factor. The result of factor analysis by AHP method and TOPSIS method are 1. Changi International airport 2. Suvarnabhumi International Airport 3. Kuala Lumpur International Airport. The model for decision making from this research indicates the importance of relevant criteria to select the airport to be the airport hub of the region. The alternative countries can also plan their policies and strategies to prepare themselves for the competitiveness in AEC era.

The suggestions of this research are as follows; 1. How to be airport hub for the region needs close corporation from all parties both airports and public policy 2 . The importance weight criteria should applied all international airports in Southeast Asia in order to find the exact weight factor 3 . The analysis of aviation rules and regulation and planning should be more emphasized in the study. Further researcher should study whether Changi International Airport has been selected as the regional airport hub, the aviation routing need to be planned and the flight connecting route within Southeast Asia and other part of the world should be well-planned in order to maximize the benefits for every ASEAN member countries in the future.

\section{REFERENCES}

1) O'Connor, K. 1995. Airport development in Southeast Asia, J. Transp Geo., 3, (4), 269_ 279.

2) Bowen, J. 2000. Airline hubs in Southeast Asia: national economic development and nodal accessibility, J. Transp Geo., 8, 25-41.

3) Costa, F. C., Lohmann, G. and Oliverira, V. M. 2010. A model to identify airport hubs and their importance to tourism in Brazil, Research in transp eco., 26, 3-11.

4) Zhang, A. 2002. Analysis of an international air-cargo hub: the case of Hong Kong. J. Air Transp Manage., 9 (2), 123-138.

5) Kang, K. and Kim, W. Y. 2003. Study on the air cargo hub networks of the Incheon international airport, in Proceedings of the Eastern Asia society for transportation studies. 4, 195-211.

6) Homsombat, W., Lei, Z. and Fu, X. 2011. Development status and prospects for aviation hub -a comparative study of the majors airports in Southeast Asia, The Singapore Economic Review., 56(4), 573-591.

7) Dennis, N.P., (1994). "Airline hub operations in Europe." Journal of Transport Geography. 2(4) 219-233.

8) Nenem, M., and Ozkan-Gunay, E., (2012). "Determining Hub Efficiency in Europe, the Middle East, and North Africa: The Impact of Geographical Positioning." Eurasian Economic Review. Eurasia Business and Economics Society. 2(2), 37-53.

9) Berechman, J., and de Wit, J., (1996). "An analysis of the effects of European aviation deregulation on an airline's network structure and choice of a primary West European hub airport." Journal of Transport Economics and Policy. 30(3), 251- 274.

10) Ohashi, H., Kim, TS., Oum, T.H., and Yu, C., (2005). "Choice of air cargo transshipment airport: an application to air cargo traffic to/ from Northeast Asia." Journal of Air Transport Management. 11(3), 149-159.

11) Costa, F.C., Lohmann, G., and Oliverira, VM., (2010). "A model to identify airport hubs and their importance to tourism in Brazil." Research in transportation economics. 26, 3-11. 
12) Watanabe, D., Majima, T., Takadama, K., and Katuhara, M., (2009). "Hub airport location in air cargo system." SICE Annual Conference. 945-948.

13) Tsai, M.C., and Su, Y.S., (2002). "Political risk assessment on air logistics hub developments in Taiwan." Journal of Air Transport Management. 8(6), 373-380.

14) Lirn, T.C., (2006). "Study of airline's cargo hub airport selection- an empirical study in Taiwan." Penghu University/Kaohsiung First University of Science \& Technology.

15) Gardiner, J., Ison, S., \& Humphreys, I., (2005). "Factor influencing cargo airline's choice of airport: An international survey." Journal of air transport management. 11, 393-399.

16) Songguang, H., (2007). "A geographical analysis of air hubs in Southeast Asia." Thesis, Department of geography, National university of Singapore.

17) Wang, R., (2011). "Study on the Cause-Effect Relationship of the Service Quality Evaluation Criteria of Portal Sites." African Journal of Business Management. 4 (10), 2432-2444.

18) Fu, X., and Zhang, A., (2010). "Effects of Airport Concession Revenue Sharing on
Competition and Social Welfare." Journal of Transport Economics and Policy. 44(2), 119138.

19) Fu, X., Oum, T.H., and Zhang, A., (2010). "Air Transport Liberalization and its Impacts on Airline Competition and Air Passenger Traffic." Transportation Journal. 49 (4), 24-41.

20) Scholz, A., (2011). "Spatial network configurations of cargo airlines." Working paper series in economics.

21) Matsumoto, H. (2007). International air network structures and air traffic density of world cities, Transportation Research Part E. 43 (3), pp.269-282.

22) Janic, M., \& Reggiani, A. (2002). An Application of the Multiple Criteria Decision Making (MCDM) Analysis to the Selection of a New Hub Airport. European Journal of Transport and Infrastructure Research, vol.2, 113-141.

23) Wang, K.J., Hong, W.C., Chen, S.H., and Jiang, J.T. (2011). Strategic development trend and key factors analysis of Airport City in Taiwan, Journal of Transport Geography 19 (2011) 807-820

Paper sent to revision:

Paper ready for publication:

\section{ANNEXES}

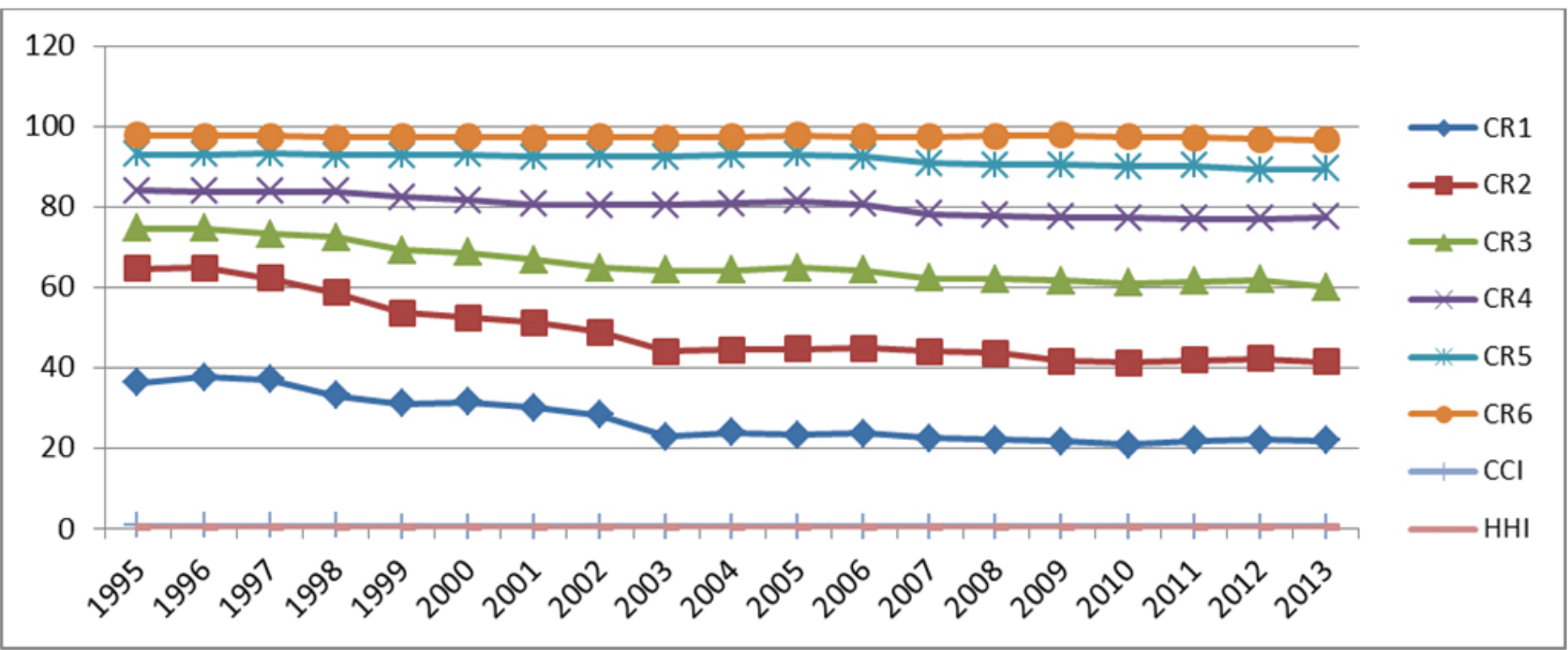

Figure 2: Show graph CR1, CR2, CR3, CR4, CR5, CR6, CCl, and HHI 
Table 3: Show Concentration Ratio, Comprehensive Concentration Index, and Herfindahi - Hirsch man index between 1995 - 2013

\begin{tabular}{|c|c|c|c|c|c|c|c|c|c|c|c|c|c|c|c|c|c|c|c|c|}
\hline Year & 1995 & 1996 & 1997 & 1998 & 1999 & 2000 & 2001 & 2002 & 2003 & 2004 & 2005 & 2006 & 2007 & 2008 & 2009 & 2010 & 2011 & 2012 & 2013 & $X$ \\
\hline CR1 & 36.16 & 37.59 & 36.99 & 33.00 & 31.01 & 31.33 & 30.01 & 28.29 & 22.86 & 23.87 & 23.25 & 23.68 & 22.39 & 22.06 & 21.69 & 20.84 & 21.89 & 22.04 & 21.76 & 26.88 \\
\hline CR2 & 64.58 & 64.74 & 62.18 & 58.56 & 53.55 & 52.40 & 51.17 & 48.74 & 44.09 & 44.38 & 44.68 & 44.83 & 44.00 & 43.60 & 41.61 & 41.11 & 41.89 & 42.26 & 41.34 & 48.93 \\
\hline CR3 & 74.52 & 74.49 & 73.15 & 72.29 & 69.22 & 68.53 & 66.70 & 64.75 & 64.19 & 64.22 & 64.71 & 64.16 & 62.12 & 61.99 & 61.50 & 61.03 & 61.29 & 61.79 & 60.06 & 65.83 \\
\hline CR4 & 84.02 & 83.78 & 83.77 & 83.68 & 82.31 & 81.67 & 80.59 & 80.37 & 80.37 & 80.78 & 81.35 & 80.47 & 78.26 & 77.72 & 77.39 & 77.18 & 77.03 & 77.00 & 77.37 & 80.27 \\
\hline CR5 & 92.97 & 93.03 & 93.17 & 92.73 & 92.77 & 92.92 & 92.35 & 92.46 & 92.38 & 92.72 & 92.98 & 92.41 & 90.74 & 90.44 & 90.30 & 90.03 & 90.20 & 89.16 & 89.34 & 91.74 \\
\hline CR6 & 97.68 & 97.61 & 97.54 & 97.19 & 97.40 & 97.41 & 97.23 & 97.32 & 97.18 & 97.27 & 97.67 & 97.43 & 97.45 & 97.53 & 97.69 & 97.37 & 97.13 & 96.83 & 96.64 & 97.35 \\
\hline $\mathrm{CCl}$ & 0.556 & 0.559 & 0.546 & 0.529 & 0.505 & 0.501 & 0.492 & 0.483 & 0.462 & 0.467 & 0.468 & 0.465 & 0.453 & 0.451 & 0.448 & 0.443 & 0.447 & 0.445 & 0.443 & 0.48 \\
\hline $\mathrm{HHI}$ & 0.241 & 0.244 & 0.235 & 0.216 & 0.202 & 0.201 & 0.195 & 0.189 & 0.181 & 0.182 & 0.184 & 0.183 & 0.179 & 0.179 & 0.178 & 0.177 & 0.177 & 0.176 & 0.176 & 0.19 \\
\hline
\end{tabular}

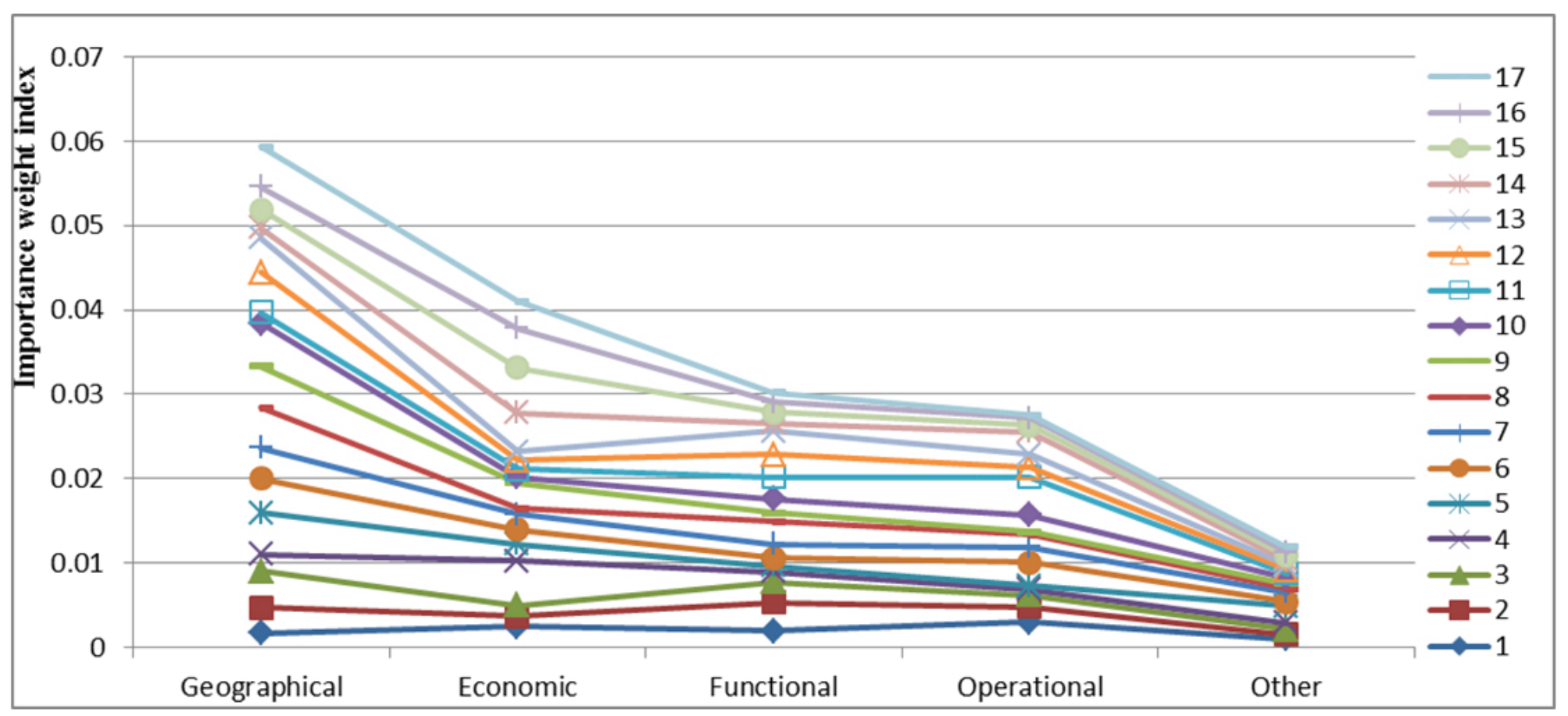

Figure 4: The weight of the importance of the main factors analyzed by AHP method 


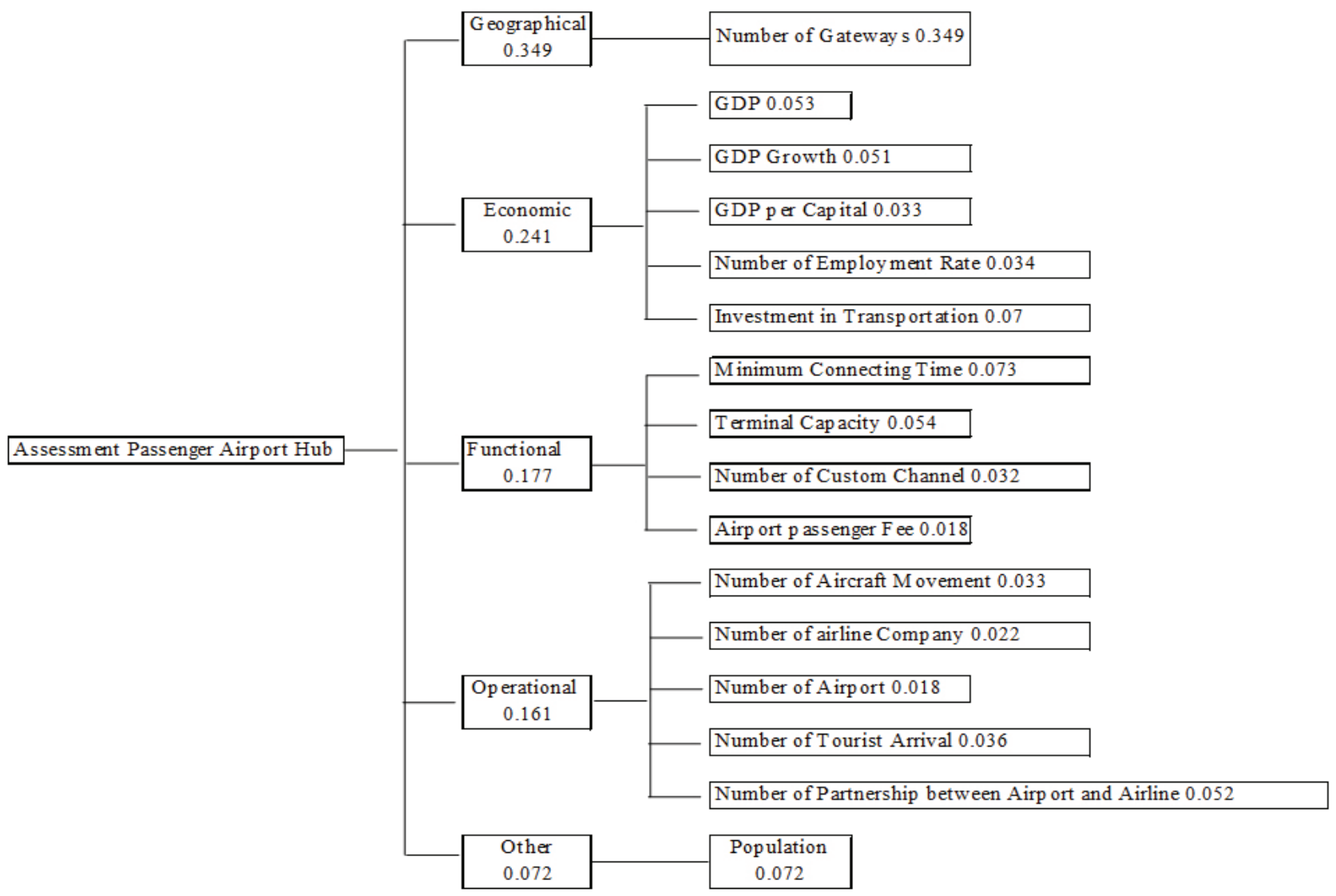

Figure 3: The result of importance weights criteria

Table 5: The results of decision making analysis by using TOPSIS method and ranking the suitable options

\begin{tabular}{|c||c|c|c|c|}
\hline Airport & S+ & S- & CC & Ranking \\
\hline \hline BKK & 0.177 & 0.154 & 0.465 & 2 \\
\hline SIN & 0.087 & 0.309 & 0.780 & 1 \\
\hline KUL & 0.202 & 0.134 & 0.400 & 3 \\
\hline CGK & 0.266 & 0.113 & 0.298 & 5 \\
\hline SGN & 0.322 & 0.030 & 0.085 & 6 \\
\hline MNL & 0.240 & 0.106 & 0.305 & 4 \\
\hline
\end{tabular}

Table 6: The result of AHP method

\begin{tabular}{|c|c|c|}
\hline Alternatives & $\begin{array}{c}\text { Preference } \\
\text { Scale }\end{array}$ & $\begin{array}{c}\text { Preference } \\
\text { Score }\end{array}$ \\
\hline BKK & 0.197 & 2 \\
\hline SIN & 0.278 & 1 \\
\hline KUL & 0.164 & 3 \\
\hline CGK & 0.16 & 4 \\
\hline SGN & 0.082 & 6 \\
\hline MNL & 0.117 & 5 \\
\hline
\end{tabular}


Table 4: Assessment forms in five level for airport alternate in Southeast Asia

\begin{tabular}{|c|c|c|c|c|c|c|c|}
\hline Main criteria & Sub-criteria & unit & level 1 (1 mark) & level 2 (3 mark) & level 3 (5 mark) & level 4 (7 mark) & level 5 (9 mark) \\
\hline Location & Number of Gateway & $\begin{array}{l}\text { count } \\
\text { by city }\end{array}$ & Below 79.4 & $79.4-120.8$ & $120.8-162.2$ & $162.2-203.6$ & More than 203.6 \\
\hline \multirow{5}{*}{ Economic } & GDP & US\$ & $\begin{array}{c}\text { Below } \\
132,394,004,172.43\end{array}$ & $\begin{array}{r}132,394,004,172.43- \\
195,714,406,998\end{array}$ & $\begin{array}{r}195,714,406,998.28- \\
259,034,809,824.13\end{array}$ & $\begin{array}{r}259,034,809,824.13- \\
322,355,212,650\end{array}$ & More than 203.6 \\
\hline & GDP Growth & $\%$ & Below 4.22 & $4.22-5.02$ & $5.02-5.82$ & $5.82-6.62$ & $\begin{array}{c}\text { More than } \\
322,355,212,650\end{array}$ \\
\hline & GDP per Capital & US\$ & Below 7,198.44 & $7,198.44-13,577.41$ & $13,577.41-19,956.38$ & $19,956.38-26,335.35$ & More than 6.62 \\
\hline & $\begin{array}{l}\text { Number of } \\
\text { employment rate }\end{array}$ & $\%$ & Below 70.58 & $70.58-90.32$ & $90.32-110.06$ & $110.06-129.8$ & More than $26,335.35$ \\
\hline & $\begin{array}{l}\text { Investment in } \\
\text { Transportation }\end{array}$ & US\$ & Below $280,407,196.45$ & $\begin{array}{r}280,407,196.45- \\
423,665,999.85\end{array}$ & $\begin{array}{l}423,665,999.85- \\
566,924,803.25\end{array}$ & $\begin{array}{r}566,924,803.25- \\
710,183,606.65\end{array}$ & $\begin{array}{c}\text { More than } \\
710,183,606.65\end{array}$ \\
\hline \multirow{4}{*}{ Functional } & $\begin{array}{c}\text { Minimum } \\
\text { Connecting Time }\end{array}$ & $\min$ & More than 60 & None & None & None & Below 60 \\
\hline & Terminal Capacity & $\mathrm{m}^{2}$ & Below 204,108.63 & $\begin{array}{r}204,108.63- \\
408,217.26\end{array}$ & $408,217.26-612,325.89$ & $\begin{array}{r}612,325.89- \\
816,434.52\end{array}$ & $\begin{array}{l}\text { More than } \\
816,434.52\end{array}$ \\
\hline & $\begin{array}{c}\text { Number of Custom } \\
\text { Channel }\end{array}$ & counter & Below 21.2 & $21.2-28.4$ & $28.4-35.6$ & $35.6-42.8$ & More than 42.8 \\
\hline & $\begin{array}{l}\text { Passenger airport } \\
\text { charge fee }\end{array}$ & US\$ & More than 17.08 & $14.56-17.08$ & $12.04-14.56$ & $9.52-12.04$ & Below 9.52 \\
\hline \multirow{5}{*}{ Operational } & $\begin{array}{l}\text { Number of Aircraft } \\
\text { Movement }\end{array}$ & count & Below $98,550.76$ & $\begin{array}{r}98,550.76- \\
129,067.58\end{array}$ & $129067.58-159,584.40$ & $\begin{array}{r}159,584.40- \\
190,101.22\end{array}$ & $\begin{array}{l}\text { More than } \\
190,101.22\end{array}$ \\
\hline & $\begin{array}{c}\text { Number of airline } \\
\text { company }\end{array}$ & count & Below 27.59 & $27.59-37.29$ & $37.29-46.99$ & $46.99-56.69$ & More than 56.69 \\
\hline & Number of Airport & count & Below 7.08 & $7.08-12.16$ & $12.16-17.24$ & $17.24-22.32$ & More than 22.32 \\
\hline & $\begin{array}{c}\text { Number of tourist } \\
\text { arrival }\end{array}$ & count & Below 6,856,479.21 & $\begin{array}{l}6,856,479.21- \\
11,093,011.07\end{array}$ & $\begin{array}{r}11,093,011.07- \\
15,329,542.92\end{array}$ & $\begin{array}{r}15,329,542.92- \\
19,566,074.77\end{array}$ & $\begin{array}{c}\text { More than } \\
19,566,074.77\end{array}$ \\
\hline & $\begin{array}{c}\text { Number of Partnership } \\
\text { between Airport and } \\
\text { Airlines }\end{array}$ & count & Below 3.8 & $3.8-4.49$ & $4.49-5.18$ & $5.18-5.87$ & More than 5.87 \\
\hline Other & Population & count & Below 47,851,668.08 & $\begin{array}{c}47,851,668.08- \\
91,305,688.79\end{array}$ & $\begin{array}{l}91,305,688.79- \\
134,759,709.50\end{array}$ & $\begin{array}{l}134,759,709.5- \\
178,213,730.20\end{array}$ & $\begin{array}{c}\text { More than } \\
178,213,730.2\end{array}$ \\
\hline
\end{tabular}

